\title{
Renal function derangements in hypothyroidism: A clinical correlation between serum creatinine, urea and uric acid levels
}

\author{
Ajay Kumar Singh ${ }^{1}$, Raj Kumar ${ }^{2, *}$, Ashish Sharma ${ }^{3}$, Dharambeer Sharma ${ }^{4}$, Saurabha Srivastava ${ }^{5}$ \\ ${ }^{\mathbf{1}}$ Assistant Professor, ${ }^{\mathbf{A}}$ Associate Professor, ${ }^{\mathbf{3}}$ Tutor, ${ }^{\mathbf{4}}$ Associate Professor, ${ }^{\mathbf{5}}$ Research Associate, Dept. of Biochemistry, ${ }^{\mathbf{1 , 3}} \mathrm{MRA}$ \\ Medical College, Ambedkar Nagar, Uttar Pradesh, ${ }^{2}$ B.R.D. Medical College, Gorakhpur, Uttar Pradesh, ${ }^{4}$ Government Medical \\ College, Banda, Uttar Pradesh, ${ }^{5}$ Jamia Millia Islamia, (A Central University), New Delhi, India
}

\author{
*Corresponding Author: Raj Kumar \\ Email: akhandrajk@gmail.com
}

\begin{abstract}
Thyroid hormones (TH) are essential for an adequate development and kidney maturity. The dysfunction of thyroid causes striking changes in glomerular and tubular capacities and electrolyte and water homeostasis. Hypothyroidism is affiliated with a decline in glomerular filtration, hyponatremia, and a modification of the capacity for water extraction. Since various renal function derangements occur in hypothyroidism, therefore, present study has been intended to determine the various parameters (urea, creatinine and uric acid) related to renal function in hypothyroid patients and correlation of these parameters with thyroid hormones (T3, T4, TSH). The study was conducted on 200 hypothyroidisms. Age and sex matched healthy euthyroids were selected for the study. Serum was taken from each patient and control and was analyzed for T3 by competitive analog-based immunoassay, T4 by competitive analog-based immunoassay, TSH by 2 site chemiluminescent immunometric assay, creatinine by modified Jaffe's method, urea by urease method and uric acid by uricase method respectively. A total number of 300 cases that includes 200 hypothyroid patients (25\% males and 75\% females) and 100 controls (42\% males and 58\% females) were examined. The mean level of serum T3 $(1.968 \pm 0.1195 \mathrm{pg} / \mathrm{ml})$, serum T4 $(1.0152 \pm 0.1235 \mathrm{pg} / \mathrm{ml})$, serum urea $(33 \pm$ $5.570 \mathrm{mg} / \mathrm{dl})$ of hypothyroids were significantly lower as compared to mean level of serum T3 $(3.704 \pm 0.1699 \mathrm{pg} / \mathrm{ml}), \mathrm{serum} \mathrm{T} 4$ $(1.5764 \pm 0.16230 \mathrm{pg} / \mathrm{ml})$ and serum urea $(35.12 \pm 3.710 \mathrm{mg} / \mathrm{dl})$ of euthyroids. The mean level of serum TSH $(8.928 \pm$ $0.9589 \mu \mathrm{IU} / \mathrm{ml})$ serum Creatinine $(2.192 \pm 0.2566 \mathrm{mg} / \mathrm{dl})$ and serum uric acid $(4.224 \pm 0.6554 \mathrm{mg} / \mathrm{dl})$ of hypothyroids were significantly higher as compared to mean level of serum TSH $(3.06 \pm 0.4110 \mu \mathrm{IU} / \mathrm{ml})$, serum Creatinine $(0.852 \pm 0.1396 \mathrm{mg} / \mathrm{dl})$ and serum uric acid $(3.772 \pm 0.2975 \mathrm{mg} / \mathrm{dl})$ of euthyroids. Hypothyroids serum T3 significantly correlated with positive person serum uric acid $(\mathrm{r}=0.343)$. Hypothyroids serum T4 indicate noteworthy negative Pearson relationship with serum urea $(\mathrm{r}=-$ $0.367)$ and creatinine $(r=-0.267)$ Hypothyroids serum TSH indicate huge negative Pearson connection with serum uric acid $(r=$ - 0.190) and creatinine $(\mathrm{r}=-0.344)$. Elevated serum creatinine, serum urea and serum uric acid demonstrates renal capacity disturbances in hypothyroidism.
\end{abstract}

Keywords: Thyroid hormones, T3, T4, TSH, Serum creatinine, Serum uric acid.

\section{Introduction}

Hypothyroidism is a clinical state caused by any structural or functional derangement that interferes with the production of adequate levels of thyroid hormone. ${ }^{1}$ Hypothyroidism has high prevalence among the elderly peoples. Among individuals over 60 years old, it affects $10 \%$ of women and $2 \%$ of men. ${ }^{2}$

THs are fundamental for a satisfactory development and advancement of the kidney. Thyroid brokenness causes exceptional changes in glomerular and tubular capacities and electrolyte and water homeostasis. Hypothyroidism is joined by a lessening in glomerular filtration, hyponatremia, and a modification of the capacity for water discharge. Over the top levels of TH create an expansion in glomerular filtration rate and renal plasma stream. ${ }^{3}$

For many decades it has been known that there is a close relationship between hypothyroidism and renal dysfunction. Hypothyroidism associated with altering systemic hemodynamic that affects both blood pressure and renal function. Thyroid hormones are necessary for maintenance of water and electrolyte homeostasis.
Many research studies have suggested that hypothyroidism should be evaluated in patients with kidney abnormalities. ${ }^{4,5}$

Children with congenital hypothyroidism have an increased prevalence of congenital renal abnormalities.

Since various renal function derangements occur in hypothyroidism, therefore, present study has been intended to determine the various parameters (urea, creatinine and uric acid) related to renal function in hypothyroid patients and correlation of these parameters with thyroid hormones (T3, T4, TSH).

\section{Materials and Methods}

Study Design and Subjects: The study was conducted on patients with hypothyroidism on case control based investigation. Age and sex matched normal healthy controls were selected for the study. The study was conducted over a period of two years in the area of Ambedkar Nagar, Uttar Pradesh, India, with the investigation of M.R.A. Medical College, Ambedkar Nagar, Uttar Pradesh. 
Inclusion Criteria: History, physical examination and elevated serum TSH level diagnosed 200 hypothyroid patients in the age group 30-60 years and 100 age and sex matched healthy subjects as controls.

Exclusion Criteria: Patients with renal diseases, chronic renal failure and other systemic diseases.

Sample Collection: All the samples were collected after overnight fasting for 8 hours about $5 \mathrm{ml}$ of venous blood was drawn with aseptic precaution from antecubital vein of the entire subject and dispensed into plain vials.

Analysis of Sample: Serum separated from plain vial after centrifugation was used for estimation of serum $\mathrm{T} 3$ (pg/ml) by competitive analog-based immunoassay, serum $\mathrm{T} 4$ by $(\mathrm{pg} / \mathrm{ml})$ by competitive analog-based immunoassay, serum TSH $(\mu \mathrm{IU} / \mathrm{ml})$ by 2 site chemiluminescent immunometric assay, creatinine $(\mathrm{mg} / \mathrm{dl})$ by modified Jaffe's method, urea $(\mathrm{mg} / \mathrm{dl})$ by urease method and uric acid $(\mathrm{mg} / \mathrm{dl})$ by uricase method.

\section{Statistical Analysis}

Mean \pm SD were calculated for all the parameters analyzed and were compared by Student's t-test (paired) and correlated by Pearson correlation using SPSS 16.0 for windows. The levels of significance were denoted as P-values ( $\mathrm{P}<0.05-\mathrm{As}$ significant and $\mathrm{P}<0.001-$ As highly significant).

\section{Results}

A total number of 300 cases that includes 200 hypothyroid patients (25\% males and $75 \%$ females) and 100 controls ( $42 \%$ males and $58 \%$ females) were examined.

The mean level of serum T3 $(1.968 \pm 0.1195$ $\mathrm{pg} / \mathrm{ml})$, serum T4 $(1.0152 \pm 0.1235 \mathrm{pg} / \mathrm{ml})$, serum urea $(33 \pm 5.570 \mathrm{mg} / \mathrm{dl})$ of hypothyroids were significantly lower as compared to mean level of serum T3 (3.704 \pm $0.1699 \mathrm{pg} / \mathrm{ml})$, serum T4 $(1.5764 \pm 0.16230 \mathrm{pg} / \mathrm{ml})$ and serum urea $(35.12 \pm 3.710 \mathrm{mg} / \mathrm{dl})$ of euthyroids.

The mean level of serum TSH (8.928 \pm $0.9589 \mu \mathrm{IU} / \mathrm{ml})$ serum Creatinine $(2.192 \pm 0.2566 \mathrm{mg} / \mathrm{dl})$ and serum uric acid $(4.224 \pm 0.6554 \mathrm{mg} / \mathrm{dl})$ of hypothyroids were significantly higher as compared to mean level of serum TSH $(3.06 \pm 0.4110 \mu \mathrm{IU} / \mathrm{ml})$, serum Creatinine $(0.852 \pm 0.1396 \mathrm{mg} / \mathrm{dl})$ and serum uric acid $(3.772 \pm 0.2975 \mathrm{mg} / \mathrm{dl})$ of euthyroids.

Hypothyroids serum T3 show significant positive Pearson correlation with serum uric acid $(r=0.343)$ but not with serum urea and creatinine. Hypothyroids serum T4 show significant negative Pearson correlation with serum urea $(r=-0.367)$ and creatinine $(r=-0.267)$ but not with serum uric acid. Hypothyroids serum TSH show significant negative Pearson correlation with serum uric acid $(r=-0.190)$ and creatinine $(r=-0.344)$ but not with serum urea.

Table 1: Characteristics of study subjects

\begin{tabular}{|l|c|c|c|c|c|}
\hline \multicolumn{3}{|c|}{ Hypothyroids } & \multicolumn{3}{c|}{ Euthyroids } \\
\hline Sex & Number & Percentage & Sex & Number & Percentage \\
\hline Males & 50 & $25 \%$ & Males & 42 & $42 \%$ \\
\hline Females & 150 & $75 \%$ & Females & 58 & $58 \%$ \\
\hline Total & 200 & & Total & 100 & \\
\hline
\end{tabular}

Table 2: Shown the various parameters of renal function in hypothyroids and controls

\begin{tabular}{|l|c|c|c|c|}
\hline \multicolumn{2}{|c|}{ Parameters } & Urea & Uric acid & Creatinine \\
\hline \multirow{3}{*}{ Serum T3 } & Pearson Correlation & -0.008 & $0.343^{* *}$ & -0.027 \\
\cline { 2 - 5 } & Sig. (2-tailed) & 0.905 & 0.000 & 0.707 \\
\cline { 2 - 5 } & $\mathrm{N}$ & 200 & 200 & 200 \\
\hline \multirow{3}{*}{ Serum T4 } & Pearson Correlation & -0.103 & $-0.190^{* *}$ & $-0.344^{* * *}$ \\
\cline { 2 - 5 } & Sig. (2-tailed) & 0.147 & 0.007 & 0.000 \\
\cline { 2 - 5 } & $\mathrm{N}$ & 200 & 200 & 200 \\
\hline \multirow{3}{*}{ Serum TSH } & Pearson Correlation & $-0.367^{* *}$ & 0.112 & $-0.267^{* *}$ \\
\cline { 2 - 5 } & Sig. (2-tailed) & 0.000 & 0.116 & 0.000 \\
\cline { 2 - 5 } & $\mathrm{N}$ & 200 & 200 & 200 \\
\hline
\end{tabular}

Table 3: Correlation of different variables (TSH, T3, and T4) with urea, creatinine and uric acid

\begin{tabular}{|l|c|c|c|c|}
\hline \multicolumn{1}{|c|}{ Parameters } & $\begin{array}{c}\text { Hypothyroids } \\
(\text { Mean } \pm \text { SE) }\end{array}$ & $\begin{array}{c}\text { Euthyroids } \\
(\text { Mean } \pm \text { SE) }\end{array}$ & Z- value & P-value \\
\hline T3 $(\mathrm{pg} / \mathrm{ml})$ & $1.968 \pm 0.1195$ & $3.704 \pm 0.1699$ & 91.479 & 0.000 \\
\hline $\mathrm{T} 4(\mathrm{pg} / \mathrm{ml})$ & $1.0152 \pm 0.1235$ & $1.5764 \pm 0.16230$ & 30.354 & 0.000 \\
\hline $\mathrm{TSH}(\mu \mathrm{IU} / \mathrm{ml})$ & $8.928 \pm 0.9589$ & $3.06 \pm 0.4110$ & 74.102 & 0.000 \\
\hline Urea $(\mathrm{mg} / \mathrm{dl})$ & $33 \pm 5.570$ & $35.12 \pm 3.710$ & 3.918 & 0.000 \\
\hline Creatinine $(\mathrm{mg} / \mathrm{dl})$ & $2.192 \pm 0.2566$ & $0.852 \pm 0.1396$ & 58.525 & 0.000 \\
\hline Uric $\mathrm{acid}(\mathrm{mg} / \mathrm{dl})$ & $4.224 \pm 0.6554$ & $3.772 \pm 0.2975$ & 8.208 & 0.000 \\
\hline
\end{tabular}

** Correlation is significant at the 0.01 level (2-tailed). 


\section{Discussion}

The present case-control based investigation assessed the biochemical parameters of renal capacity in hypothyroid subjects and contrasted the outcomes and those of euthyroid and also the connection of different renal parameters with thyroid hormones (T3, $\mathrm{T} 4$ and TSH). This examination demonstrates that there is a huge increment in serum creatinine and serum uric acid levels in hypothyroid patients when contrasted with euthyroid while there is a huge abatement in serum urea in hypothyroid when contrasted with euthyroid. Serum urea demonstratesahuge negative connection with serum TSH and uric corrosive show noteworthy positive relationship with serum T3 and huge negative connection with serum $\mathrm{T} 4$ while serum creatinine indicates critical negative connection serum $\mathrm{T} 4$ and serum TSH.

Earlier, similar result for serum creatinine has also reported. ${ }^{6,7}$ Relatively comparable changes in serum creatinine with hypothyroidism have been accounted for in segregated contextual investigations and couple of different examinations having lesser number of hypothyroid patients. ${ }^{8}$ Indeed, even newborn children with intrinsic hypothyroidism have demonstrated higher serum creatinine levels in the extent of the seriousness of hypothyroidism, however, no impacts were seen on serum urea levels. The consistency of raised serum creatinine in this investigation with different examinations. ${ }^{9}$ Hypothyroidism influence renal bloodstream, GFR, tubularfunction, electrolytes homeostasis, and electrolyte pump capacities, and kidney structure. ${ }^{10}$

Essential hypothyroidism is related to a reversible height of serum creatinine in both adults ${ }^{11}$ and children. ${ }^{12}$ The expanded serum uric acid in hypothyroid shows either expanded creation because of myopathy related with hypothyroidism or because of diminished renal discrepancy of uric acid. ${ }^{13}$ Histopathological changes in cellar film thickening in nephrons have been exhibited in both hypothyroid inrats ${ }^{14}$ and humans. ${ }^{15}$

Physiological impacts incorporate changes in water and electrolyte homeostasis, strikingly hyponatremia, and adjustments of renal hemodynamics ${ }^{16}$ incorporating decrements in renalbloodstream, renal plasma stream, glomerular filtration rate (GFR), and single nephron GFR. The reason for the diminished renal plasma stream and GFR watched is accepted to be basically due to the summed up hypodynamic condition of the circulatory framework in hypothyroidism. GFR esteems in myxedematous patients are by and large 33\% lower than the qualities in euthyroid individuals. ${ }^{17}$

Other conceivable component thyroid hormone activity on renal capacity could be clarified by its impact on the development of the renin-angiotensin framework (RAAS). Plasma renin movement and plasma levels of angiotensinogen, angiotensin II and aldosterone are specifically identified with plasma levels of thyroid hormones..$^{18}$ Hypothyroidism is related to low plasma rennin. ${ }^{19}$ This examination affirms that the hypothyroid state is related to a predictable elevation in the serum creatinine and uric acid levels, apparently because of a decline in the GFR or modification in RAAS.

A noteworthy connection between's thyroid capacity and purine nucleotide digestion has been built up in hypothyroidism. Giordano et al. contemplated 28 patients with essential hypothyroidism and found a critical increment in the occurrence of both hyperuricemia and gout in the hypothyroid patients. ${ }^{20}$ Erickson and associate have tentatively assessed that the 54 patients with a recorded gouty joint inflammation for the nearness of hypothyroidism. ${ }^{21}$

The prevalence of hypothyroidism was significantly higher in patients with gouty arthritis. Overall, $15 \%$ of these patients, $25 \%$ of women and $12 \%$ of men, had hypothyroidism. These rates were 2.5 -fold greater in women and six fold greater in men than found in the controls. Moreover, our study showed that hyperuricemia in hypothyroidism is related to elevated serum creatinine and diminished creatinine discrepancy. This reality recommends that hypothyroid hyperuricemia is optional to a lessening in renal plasma stream and glomerular filtration, officially very much showed in thyroid hormone lack disorders.

Hypothyroidism-related kidney brokenness is by all accounts more related to the decrease in thyroid hormone levels as opposed to with thyroid autoimmunity. ${ }^{22}$ Among the instruments engaged with hypothyroidism-related kidney confusions are immediate impacts of $\mathrm{TH}$ on the cardiovascular framework (expanded fringe protection and lessening of myocardial contractility and stroke volume) and digestion (hyperlipidemia), and backhanded impacts through paracrine or endocrine middle people, for example, insulin-like development factor write 1 (IGF1) and vascular endothelial development factor. ${ }^{23}$

The reversible relationship amongst hypothyroidism and elevated serum creatinine and uric acid are critical for a clinician. This data maintain a strategic distance from pointless examinations, treatment cost and stress in patients giving either expanded creatinine or gout with undetermined thyroid status. The appraisal of thyroid capacity ought to be routinely completed for assessment of patients giving unhinged renal capacity.

\section{Acknowledgement}

The authors are thankful to the Principal, Head of Department of Medicine and Head of Department of Biochemistry as well as Library staff who have given prompt and proper reference services for this study and B.R.D. Medical College Gorakhpur, Uttar Pradesh, MRA Medical College, Ambedkar Nagar, Uttar Pradesh and Govt. Medical College, Banda, Uttar Pradesh, India for providing facilities for research. 
Conflict of Interest: All the authors have declared that, there has been no conflict of interest at any stage of the study.

\section{References}

1. Kumar V, Fausto N, Abbas AK, Cotran RS, Robbins, Stanley L. Robbins and Cotran Pathologic Basis of Disease. $8^{\text {th }}$ Ed. Philadelphia: Saunders. 2010;1194-5.

2. Rehman SU, Cope DW, Senseney AD, Brzezinski W. Thyroid disorders in elderly patients. South Med J. 2005;98(5):543-9.

3. Iglesias P and Di'ez J J. Thyroid dysfunction and kidney disease. Eup J Endocrinology. 2009;160 503-15.

4. Mahjoub S, Ben Dhia N, Achour A. Hypothyroïdie primitive et atteinteglomérulaire. [Primary hypothyroidism and glomerular involvement]. Ann Endocrinol (Paris). 1991;52(4):289-92.

5. Ogata S, Yorioka N, Tanji C. Two cases of hypothyroidism complicated by renal dysfunction. Hiroshima J Med Sci. 2000;49(1):93-6.

6. Chaudhury HS, Raihan KK, Uddin MN, Ansari SM, Hasan M, Ahmed M, Kabir MF, Hoque MZ. Renal function impairment in Hypothyroidism. Bangladesh $J$ Med Biochem. 2013;6(1):19-25.

7. Tayal D, Chawla R,Arora S, Gupta VK, Sohi JS Mallika V. Dynamic changes in biochemical markers of renal function with thyroid status - A study in Indian population. Int J Med Update. 2009;4(2):36-41.

8. del-Río Camacho G, Tapia Ceballos L, Picazo Angelín B. Renal failure and acquired hypothyroidism. Pediatr Nephrol. 2003;18(3):290-2.

9. den Hollander JG, Wulkan RW, Mantel MJ, et al. Correlation between severity of thyroid dysfunction and renal function. Clin Endocrinol (Oxf). 2005;62(4):423- 7.

10. Kaptein EM, Quion-Verde H \&Massry SG. Hemodynamic effects of thyroid hormone. Contributions to Nephrology. 1984;41:151-159.

11. Kreisman SH \& Hennessey JV. Consistent reversible elevations of serum creatinine levels in severe hypothyroidism. Archives of Internal Medicine. 1999;59:79-82.

12. Al-Fifi S, Girardin C, Sharma A\& Rodd C. Moderate renal failure in association with prolonged acquired hypothyroidism in children. Acta Paediatrica. 1999;88:715-718.
13. Yokogoshi Y, Saito S. Abnormal serum uric acid level in endocrine disorders. Nippon Rinsho. 1996;54(12):3360-3.

14. Davis RG, Madsen KM, Fregly MJ. Kidney structure in hypothyroidism. Am J Pathol. 1983;113(1):41-9.

15. Capasso G, De Santo NG, Kinne R. Thyroid hormones and renal transport: Cellular and biochemical aspects. Kidney Int. 1987;32(4):443-51.

16. Montenegro J, Gonzalez O, Saracho R. Changes in renal function in primary hypothyroidism. Am J Kidney Dis. 1996;27(2):195-8.

17. Allon M, Harrow A, Pasque CB. Renal sodium and water handling in hypothyroid patients: the role of renal insufficiency. J Am Soc Nephrol. 1990;1(2):205-10.

18. Vargas F, Moreno JM, Rodríguez-Gómez I. Vascular and renal function in experimental thyroid disorders. Eur $J$ Endocrinol. 2006;154(2):197-212.

19. Bouhnik J, Galen FX, Clauser E. The renin-angiotensin system inthyroidectomized rats. Endocrinology. 1981;108(2):647-50.

20. Giordano N, Santacroce C, Mattii G, Geraci S, Amendola A, Gennari C. Hyperuricemia and gout in thyroid endocrine disorders. Clinical and Experimental Rheumatology, 2001;19:661-665.

21. Erickson AR, Erzenauer RJ, Nordstrom DM, Merenich JA. The prevalence of hypothyroidism in gout. Am J Med. 1994:97:231-34.

22. Suher M, Koc E, Ata N \&Ensari C. Relation of thyroid disfunction, thyroid autoantibodies, and renal function. Renal Failure. 2005;27:739-742.

23. Elgadi A, Verbovski P, Marcus C \& Berg UB. Long-term effects of primary hypothyroidism on renal function in children. Journal of Pediatrics. 2008;152;860-864.

How to cite this article: Singh A. K, Kumar R, Sharma A, Sharma D, Srivastava S. Renal function derangements in hypothyroidism: A clinical correlation between serum creatinine, urea and uric acid levels. Int $\mathrm{J}$ Clin Biochem Res. 2018;5(4):533-536. 